\title{
Landiolol hydrochloride for prevention of atrial fibrillation after coronary artery bypass grafting: New evidence from the PASCAL trial
}

\author{
Akira Sezai, MD, PhD, ${ }^{\mathrm{a}}$ Kazutomo Minami, MD, PhD, ${ }^{\mathrm{a}}$ Toshiko Nakai, MD, PhD, ${ }^{\mathrm{b}}$ Mitsumasa Hata, MD, \\ $\mathrm{PhD},{ }^{\mathrm{a}}$ Isamu Yoshitake, MD, PhD, ${ }^{\mathrm{a}}$ Shinji Wakui, MD, PhD,${ }^{\mathrm{a}}$ Motomi Shiono, $\mathrm{MD}, \mathrm{PhD},{ }^{\mathrm{a}}$ and \\ Atsushi Hirayama, $\mathrm{MD}, \mathrm{PhD}^{\mathrm{b}}$
}

\begin{abstract}
Objective: Atrial fibrillation occurs frequently after cardiac surgery and not only prolongs hospitalization but also influences the prognosis. We investigated whether landiolol hydrochloride, an ultrashort-acting betablocker, could reduce postoperative atrial fibrillation in a randomized controlled trial.
\end{abstract}

\begin{abstract}
Methods: The subjects were 140 patients undergoing coronary artery bypass grafting at the Nihon University School of Medicine. The primary end point was occurrence/non-occurrence of atrial fibrillation up to 1 week postoperatively. Logistic regression analysis was performed to investigate risk factors for atrial fibrillation among preoperative, perioperative, and postoperative variables.
\end{abstract}

\begin{abstract}
Results: Atrial fibrillation occurred in 7 patients $(10 \%)$ in the landiolol group versus 24 patients $(34.3 \%)$ in the placebo group; the landiolol group had a significantly lower incidence $(P=.0006)$. Postoperative heart rate was significantly lower in the landiolol group than in the placebo group. On returning to the intensive care unit, the landiolol group had significantly lower inflammatory and ischemic parameters. Medical costs were also significantly lower in the landiolol group. Multivariate analysis revealed that significant risk factors for atrial fibrillation were a European System for Cardiac Operative Risk Evaluation of 10 or more, preoperative non-use of angiotensin receptor blockers, and non-use of landiolol.
\end{abstract}

Conclusions: Postoperative atrial fibrillation was reduced by treatment with landiolol hydrochloride. Amelioration of ischemia, an anti-inflammatory effect, and inhibition of sympathetic hypertonia by landiolol presumably reduced the occurrence of atrial fibrillation. Hypotension or bradycardia did not develop in any of the patients, indicating the safety of this beta-blocker. These findings suggest that landiolol hydrochloride could be useful in the perioperative management of patients undergoing cardiac surgery. (J Thorac Cardiovasc Surg 2011;141:1478-87)

Atrial fibrillation (Af) is a common complication of cardiac surgery, and its incidence has been variously reported as $16 \%$ to $85 \% .^{1-5}$ Postoperative Af prolongs the hospital stay of patients and influences both early and late survival, ${ }^{6}$ so prevention is important. It has been reported that postoperative Af is associated with advanced age, obesity, preoperative cardiac dysfunction, respiratory failure, renal impairment, inflammation, ischemia-reperfusion injury, oxidative stress, fibrosis, and sympathetic hypertonia. ${ }^{1-9}$

\footnotetext{
From the Departments of Cardiovascular Surgery ${ }^{\mathrm{a}}$ and Cardiology, ${ }^{\mathrm{b}}$ Nihon University School of Medicine, Tokyo, Japan.

This study was supported by a grant for scientific research from the Japanese Ministry of Education, Culture, Sports, Science, and Technology, and a grant for the 50th anniversary of the foundation of Nihon University School of Medicine.

Disclosures: Authors have nothing to disclose with regard to commercial support.

Clinical Trial Registration Information: UMIN (http://www.umin.ac.jp/), Study ID: UMIN000001792

Received for publication March 3, 2010; revisions received Aug 30, 2010; accepted for publication Oct 23, 2010; available ahead of print Jan 27, 2011.

Address for reprints: Akira Sezai, MD, PhD, The Department of Cardiovascular Surgery, Nihon University School of Medicine, 30-1 Oyaguchi-kamimachi Itabashi-ku Tokyo, 173-8610, Japan (E-mail: asezai@med.nihon-u.ac.jpa).

$0022-5223 / \$ 36.00$

Copyright (c) 2011 by The American Association for Thoracic Surgery doi:10.1016/j.jtcvs.2010.10.045
}

Although consensus on the causes has not been achieved, a close relationship between advanced age and the occurrence of Af was suggested by all the studies mentioned.

The efficacy of several $\beta$-blockers and amiodarone for prevention of Af has been demonstrated by randomized controlled trials (RCTs). ${ }^{4,10,11}$ The guidelines of the American College of Cardiology/American Heart Association recommend oral $\beta$-blocker therapy for patients undergoing cardiac surgery who have no contraindications to prevent postoperative Af (class I), and amiodarone is also recommended for prevention of Af (class IIa) 12). RCTs have been performed on various drugs to date, but the results have not been consistent. There are reports of postoperative $\mathrm{AF}$ incidences of less than $10 \%$, including $3 \%$ when atenolol was administered orally from preoperatively ${ }^{13}$ and $9.8 \%$ with postoperative oral administration of propranolol, ${ }^{14}$ but there have also been reports of incidences of $12.5 \%$ to $34 \%$ or no differences when drugs were used. ${ }^{4,10,11,15}$ Moreover, few RCTs have investigated prophylactic intravenous administration of $\beta$-blockers, and the efficacy of such drugs has not been proven.

The Prevention of Atrial fibrillation in patientS having CArdiac surgery with landiolol hydrochloride for coronary 


$\begin{aligned} & \text { Abbreviations and Acronyms } \\ & \text { ACE-I }=\text { angiotensin-converting enzyme } \\ & \text { inhibitor } \\ &= \text { atrial fibrillation } \\ & \text { Af } \text { angiotensin receptor blocker } \\ & \text { ARB }=\text { coronary artery bypass grafting } \\ & \text { CABG } \text { creatine kinase isoenzyme MB } \\ & \text { CK-MB } \text { Operative Risk Evaluation } \\ & \text { euroSCORE }= \text { European System for Cardiac } \\ & \text { hs-CRP }=\text { highly sensitive C-reactive protein } \\ & \text { I-CTP }=\text { pyridinoline cross-linked } \\ & \text { telopeptide of type I collagen } \\ & \text { ICU } \text { intensive care unit } \\ & \text { IL } \text { interleukin } \\ & \text { KL-6 }=\text { sialylated carbohydrate antigen } \\ & \text { KL-6 } \\ & \text { PASCAL }= \text { Prevention of Atrial fibrillation in } \\ & \text { patientS having CArdiac surgery } \\ & \text { with landiolol hydrochloride } \\ & \text { RCT }=\text { randomized controlled trial }\end{aligned}$

artery bypass grafting (CABG) (PASCAL trial for CABG) was designed to investigate the efficacy of landiolol hydrochloride, an ultrashort-acting $\beta_{1}$-selective $\beta$-blocker, for prevention of postoperative Af. Landiolol was developed in Japan and released in 2002. It has a shorter half-life, ${ }^{16}$ higher $\beta_{1} / \beta_{2}$ selectivity ratio, and weaker negative inotropic effect compared with other intravenous $\beta$-blockers, so the risk of hypotension is small. ${ }^{16-18}$ Landiolol has only been approved in Japan at present, and this was the first RCT investigating its efficacy for postoperative Af.

\section{PATIENTS AND METHODS Study Protocol}

The PASCAL trial for CABG was a randomized, double-blind, placebocontrolled study. It was conducted after obtaining approval from the ethics committee of Nihon University School of Medicine Itabashi Hospital. Informed consent was provided by each patient after receiving an explanation about this study.

The subjects were patients who were scheduled to undergo CABG on cardiopulmonary bypass. We excluded patients with cardiogenic shock, sinus bradycardia (resting heart rate $\leq 50 / \mathrm{min}$ ), second- or third-degree atrioventricular block, clinical hypothyroidism or hyperthyroidism, a history of arrhythmia, and those undergoing off-pump surgery. Patients were randomized into 2 groups by the lottery method. Landiolol hydrochloride (Ono Pharmaceutical Co, Ltd, Osaka, Japan) was administered at the time of central anastomosis during CABG in the landiolol group or physiologic saline was administered in the placebo group. Patients were treated in a blinded manner. Landiolol infusion was started at $2 \mu \mathrm{g} / \mathrm{kg} / \mathrm{min}$ and discontinued after 48 hours. If the heart rate was 90 beats/min or less, right atrial pacing was performed at a rate of 90 times/min for 48 hours. CABG was performed with cardiopulmonary bypass (Jostra HL-20, Jostra Inc, Hirrlingen, Germany) and nonpulsatile perfusion at a tepid temperature (rectal temperature: $34^{\circ} \mathrm{C}$ ) by the intermittent aortic crossclamp method without cardioplegic solution. In all patients, the left internal thoracic artery was anastomosed to the left anterior descending coronary artery, and radial artery or saphenous vein grafts were used for other vessels.

The pulse rate was monitored to detect Af for 1 week after surgery by continuous electrocardiographic monitoring. Occurrence of Af was defined as persistence of this arrhythmia for 5 minutes or more or a requirement for treatment because of hemodynamic changes. In this study, patients who had postoperative Af were treated with amiodarone hydrochloride, pilsicainide hydrochloride, or digitalis. The protocol avoided the use of oral $\beta$-blockers as much as possible; they were used only when it was considered necessary in patients with conditions such as left ventricular dysfunction.

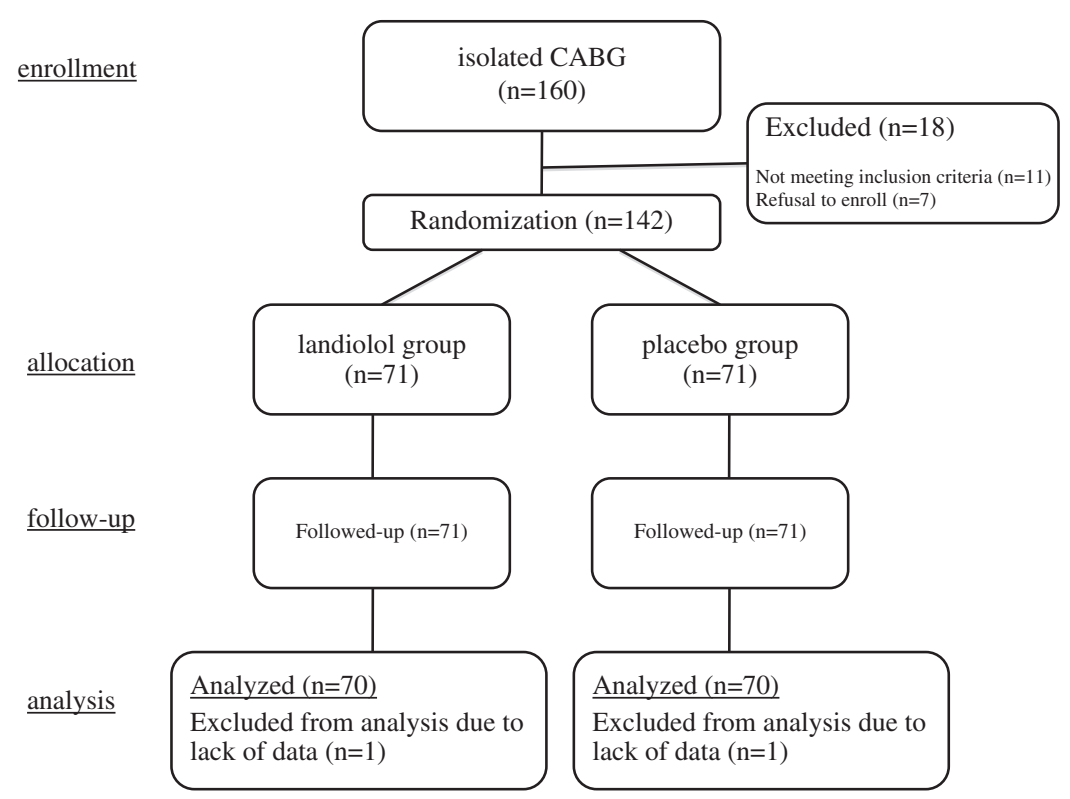


TABLE 1. Comparison of clinical characteristics and measured data

\begin{tabular}{|c|c|c|c|}
\hline & $\begin{array}{l}\text { Landiolol } \\
\text { group }\end{array}$ & $\begin{array}{c}\text { Placebo } \\
\text { group }\end{array}$ & $\begin{array}{c}P \\
\text { value }\end{array}$ \\
\hline No. & 70 & 70 & \\
\hline Age $(y)$ & $68.5 \pm 4.7$ & $66.7 \pm 8.9$ & .2423 \\
\hline Gender (male: female) & $62: 8$ & 66: 4 & .3660 \\
\hline Body surface area $\left(\mathrm{m}^{2}\right)$ & $1.69 \pm 0.17$ & $1.73 \pm 0.17$ & .1743 \\
\hline euroSCORE & $5.2 \pm 2.9$ & $5.4 \pm 4.1$ & .7746 \\
\hline Diagnosis & & & .7899 \\
\hline Acute myocardial infarction & 6 & 8 & \\
\hline Old myocardial infarction & 27 & 24 & \\
\hline Unstable angina & 26 & 27 & \\
\hline Stable angina & 11 & 11 & \\
\hline Emergency surgery & 17 & 19 & .8469 \\
\hline \multicolumn{4}{|l|}{ Risk factors } \\
\hline Diabetes mellitus & 35 & 37 & .8658 \\
\hline Hypertension & 58 & 50 & .1582 \\
\hline Hyperlipidemia & 36 & 42 & .3950 \\
\hline Obesity & 13 & 14 & 1.00 \\
\hline Smoking & 32 & 26 & .3911 \\
\hline COPD & 3 & 2 & 1.00 \\
\hline Cerebrovascular disease & 3 & 3 & 1.00 \\
\hline Chronic renal failure & 12 & 12 & 1.00 \\
\hline \multicolumn{4}{|l|}{ Oral medications } \\
\hline ARB & 39 & 37 & .8654 \\
\hline ACE-I & 4 & 6 & .7447 \\
\hline $\mathrm{Ca}$ antagonist & 24 & 28 & .6000 \\
\hline Beta blocker & 17 & 25 & .1964 \\
\hline Aldosterone blocker & 6 & 3 & .4932 \\
\hline Statin & 19 & 26 & .2775 \\
\hline Ejection fraction $(\%)$ & $54.5 \pm 14.2$ & $55.6 \pm 13.5$ & .6598 \\
\hline $\mathrm{sBP}(\mathrm{mm} \mathrm{Hg})$ & $135.0 \pm 18.7$ & $135.3 \pm 18.6$ & .9352 \\
\hline $\mathrm{dBP}(\mathrm{mm} \mathrm{Hg})$ & $76.6 \pm 11.2$ & $78.5 \pm 12.2$ & .3496 \\
\hline $\mathrm{CVP}(\mathrm{mm} \mathrm{Hg})$ & $6.4 \pm 1.6$ & $6.7 \pm 1.6$ & .3097 \\
\hline Heart rate (beats/min) & $74.7 \pm 11.7$ & $76.1 \pm 10.7$ & .4518 \\
\hline hs-CRP (mg/dL) & $0.76 \pm 1.64$ & $0.63 \pm 1.25$ & .6141 \\
\hline IL-6 (pg/mL) & $5.7 \pm 6.4$ & $5.2 \pm 8.1$ & .8289 \\
\hline IL-8 (pg/mL) & $6.5 \pm 4.0$ & $5.3 \pm 3.8$ & .7037 \\
\hline CK-MB (U/L) & $62.2 \pm 48.1$ & $69.3 \pm 70.9$ & .7662 \\
\hline Urinary-OHdG (ng/mg Cr) & $11.0 \pm 5.1$ & $11.9 \pm 6.6$ & .9350 \\
\hline KL-6 (U/mL) & $222.3 \pm 89.2$ & $234.7 \pm 126.9$ & .5320 \\
\hline I-CTP (ng/mL) & $10.4 \pm 12.0$ & $9.1 \pm 9.6$ & .5369 \\
\hline Hyaluronic acid (ng/mL) & $58.0 \pm 52.9$ & $45.0 \pm 41.8$ & .1427 \\
\hline
\end{tabular}

$C O P D$, Chronic obstructive pulmonary disease; $A R B$, angiotensin II receptor blocker; $A C E-I$, angiotensin-converting enzyme inhibitor; $s B P$, systolic blood pressure; $d B P$, diastolic blood pressure; $C V P$, central venous pressure; $h s-C R P$, highly sensitive C-reactive protein; $C K-M B$, creatine kinase isoenzyme $\mathrm{MB} ; O H d G$, 8-hydroxydeoxyguanosine; $K L-6$, sialylated carbohydrate antigen KL-6; I-CTP, pyridinoline cross-linked telopeptide of type I collagen.

The primary end point was the occurrence/non-occurrence of Af during the initial 1-week period after surgery. The secondary end points were (1) operative mortality and complications; (2) hemodynamics (systolic blood pressure, diastolic blood pressure, heart rate before surgery) at the return to the intensive care unit (ICU), at 12,24, and 48 hours after administration, and at 24 hours after discontinuing administration (in patients on pacing, the pacemaker was stopped before measuring the heart rate); (3) fluid balance (during cardiopulmonary bypass and on postoperative days $0-3$ ); (4) creatine kinase isoenzyme MB (CK-MB) (at the return to ICU, 3 hours after returning, and on postoperative days 1 and 3), and troponin-I and human heart fatty acid-binding protein (at the return to ICU and on postoperative days 1 and 3) as indices of ischemia-reperfusion injury; (5) interleukin (IL)-6, IL-8, and highly sensitive C-reactive protein (hs-CRP) as indices of inflammation (before surgery, at the return to ICU, and on postoperative days 1, 3, and 7); (6) urinary 8-hydroxydeoxyguanosine as an index of oxidative stress (before surgery, on returning to ICU, and on postoperative days 1,3, and 7); and (7) the total cost of hospital treatment. Postoperative complications were categorized as central nervous system disorders, cardiovascular disorders (low output syndrome), heart failure, perioperative myocardial infarction (CK-MB of $>5$ times the normal level, abnormal ST segments or T waves on electrocardiogram, and refractory arrhythmia), respiratory failure, acute renal failure (requiring dialysis), gastrointestinal disorders (gastrointestinal bleeding, ileus, or a requirement for high-calorie alimentation, eg, in patients with liver dysfunction), infections (eg, septicemia, pneumonia, mediastinitis), and other disorders requiring long-term ICU management.

\section{Investigation of Factors Associated With Atrial Fibrillation}

The patients were compared with respect to preoperative, perioperative, and postoperative factors in relation to the occurrence of postoperative Af. Preoperative factors investigated age, gender, body surface area, euroSCORE, emergency surgery, left ventricular ejection fraction, oral drug therapy, preoperative hematology and urinalysis parameters, and markers of fibrosis (sialylated carbohydrate antigen KL-6 [KL-6], pyridinoline cross-linked telopeptide of type I collagen [I-CTP], and hyaluronic acid). Perioperative/postoperative factors were landiolol use, aortic crossclamping time, extracorporeal circulation time, hospital stay (days), and medical costs.

Logistic regression analysis was also conducted using preoperative factors (age $\geq 70$ years, male sex, euroSCORE $>10$ points, ejection fraction $<40 \%$, hs-CRP $>3.0 \mathrm{mg} / \mathrm{dL}$, preoperative oral drug therapy, KL-6 $>300 \mathrm{U} / \mathrm{mL}$, hyaluronic acid $>80 \mathrm{ng} / \mathrm{mL}$, and I-CTP $>10 \mathrm{ng} / \mathrm{mL}$ ) and perioperative factors (activated clotting time $>40 \mathrm{~min}$, extracorporeal circulation time $>120 \mathrm{~min}$, landiolol use, and postoperative oral drug therapy) to investigate associations with Af.

\section{Statistical Analysis}

Results are expressed as the mean \pm standard deviation. For parametric and nonparametric data, the significance of differences was determined with Student $t$ test and Fisher's exact test, respectively. Patients with or without Af were compared for clinical characteristics, preoperative hematology data, perioperative/postoperative parameters, and postoperative hematology data using Fisher's exact test or the unpaired Student $t$ test. Independent predictors of Af were examined by multivariate analysis using the parameters detected with univariate analysis. Other data were analyzed by repeated-measures analysis of variance.

\section{RESULTS Disposition of Patients}

The 142 patients registered in the PASCAL trial for CABG were randomized equally to 2 groups: 71 patients treated with landiolol (landiolol group) and 71 patients treated with physiologic saline (placebo group). Administration was not discontinued because of hypotension or bradycardia in either group, and all patients completed the study. However, some postoperative hematology data were missing in 1 patient each from the landiolol group and the placebo group, so the remaining 70 patients from each group were studied (Figure 1). 
TABLE 2. Perioperative and postoperative findings

\begin{tabular}{|c|c|c|c|}
\hline & $\begin{array}{l}\text { Landiolol } \\
\text { group }\end{array}$ & $\begin{array}{c}\text { Placebo } \\
\text { group }\end{array}$ & $\begin{array}{c}P \\
\text { value }\end{array}$ \\
\hline No. & 70 & 70 & \\
\hline Occurrence of Af & $7(10.0 \%)$ & $24(34.3 \%)$ & .0006 \\
\hline Days until Af & $3.4 \pm 2.3$ & $2.5 \pm 1.2$ & .1556 \\
\hline Mortality & 0 & 2 & .1699 \\
\hline Complications & 3 & 6 & .4931 \\
\hline No. of bypasses & $3.2 \pm 1.0$ & $3.2 \pm 0.8$ & .8549 \\
\hline Surgeon & & & .6965 \\
\hline Surgeon $\mathrm{M}$ & 34 & 31 & \\
\hline Surgeon $\mathrm{H}$ & 17 & 20 & \\
\hline Surgeon $\mathrm{S}$ & 19 & 19 & \\
\hline ACCT (min) & $23.4 \pm 9.1$ & $23.2 \pm 9.3$ & .9054 \\
\hline ECCT (min) & $103.1 \pm 28.3$ & $105.0 \pm 29.8$ & 6912 \\
\hline Hospital stay (d) & $11.2 \pm 4.9$ & $14.0 \pm 7.6$ & .0102 \\
\hline \multicolumn{4}{|l|}{ Oral medications } \\
\hline ARB & 32 & 36 & .6121 \\
\hline ACE-I & 2 & 3 & 1.00 \\
\hline $\mathrm{Ca}$ antagonist & 38 & 36 & .8656 \\
\hline Beta-blocker & 14 & 20 & .3245 \\
\hline Aldosterone blocker & 53 & 49 & .5689 \\
\hline Statin & 43 & 41 & .8631 \\
\hline Ejection fraction $(\%)$ & $55.2 \pm 15.0$ & $55.8 \pm 11.6$ & .7958 \\
\hline Hospital cost & $\begin{array}{c}\$ 35,679.48 \pm \\
\$ 6273.40\end{array}$ & $\begin{array}{r}\$ 39,981.43 \pm \\
\$ 13,417.62\end{array}$ & .0202 \\
\hline
\end{tabular}

Af, Atrial fibrillation; $A C C T$, aortic crossclamping time; ECCT, extracorporeal circulation time; $A R B$, angiotensin II receptor blocker; ACE-I, angiotensinconverting enzyme inhibitor.

\section{Baseline Characteristics}

As shown in Table 1, the baseline characteristics of the 2 groups showed no differences.

\section{Primary End Point}

Postoperative Af occurred in 7 patients $(10 \%)$ in the landiolol group versus 24 patients $(34.3 \%)$ in the placebo group; the landiolol group showed a significantly lower incidence $(P=.0006)$ (Table 2$)$. Most patients $(128 / 140)$ received pacing at 90 times/min immediately after surgery. In both the landiolol and placebo groups, 64 patients received

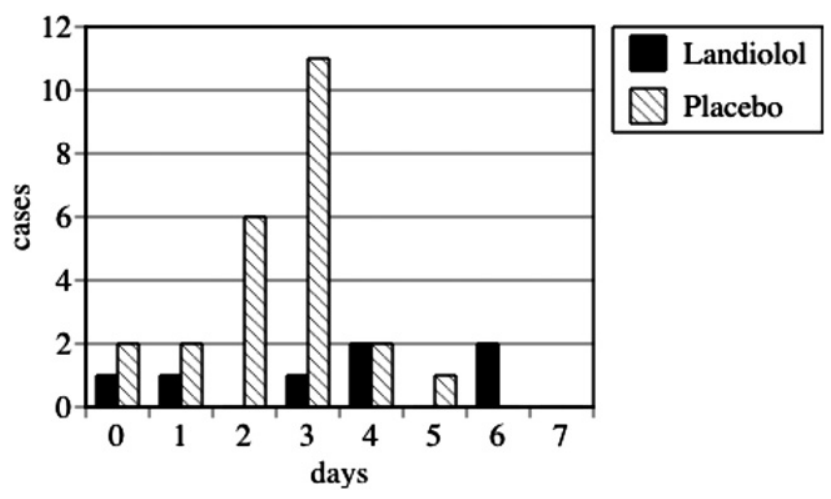

FIGURE 2. Days of occurrence of Af.
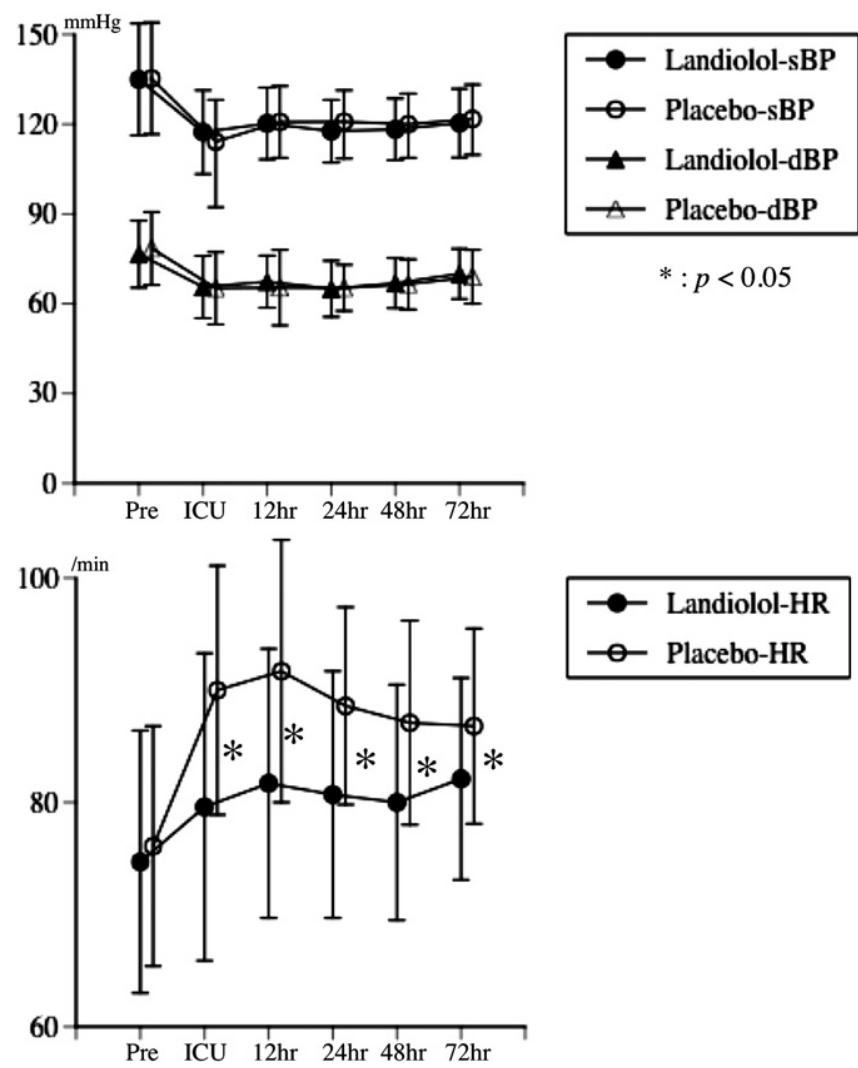

FIGURE 3. Changes of blood pressure (systolic blood pressure and diastolic blood pressure [upper]) and heart rate [lower]. Systolic and diastolic blood pressure showed no significant differences between the 2 groups, but heart rate was significantly lower in the landiolol group. $s B P$, Systolic blood pressure; $d B P$, diastolic blood pressure; $H R$, heart rate.

pacing, and there was no difference between the groups. Af occurred after $3.4 \pm 2.3$ days in the landiolol group and 2.5 \pm 1.2 days in the placebo group, showing no significant difference of onset $(P=.1556)$. Among patients with Af, more than half of the patients contracted Af after discontinuing administration of landiolol or placebo (5 patients [71.4\%] in the landiolol group and 14 patients $[58.3 \%]$ in the placebo group), but no significant differences were found

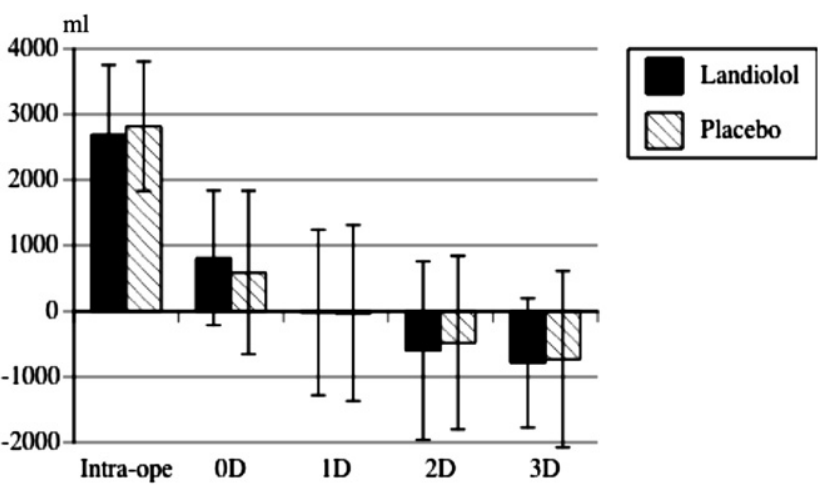

FIGURE 4. Perioperative and postoperative fluid balance: Fluid balance showed no statistically significant difference between the 2 groups. 


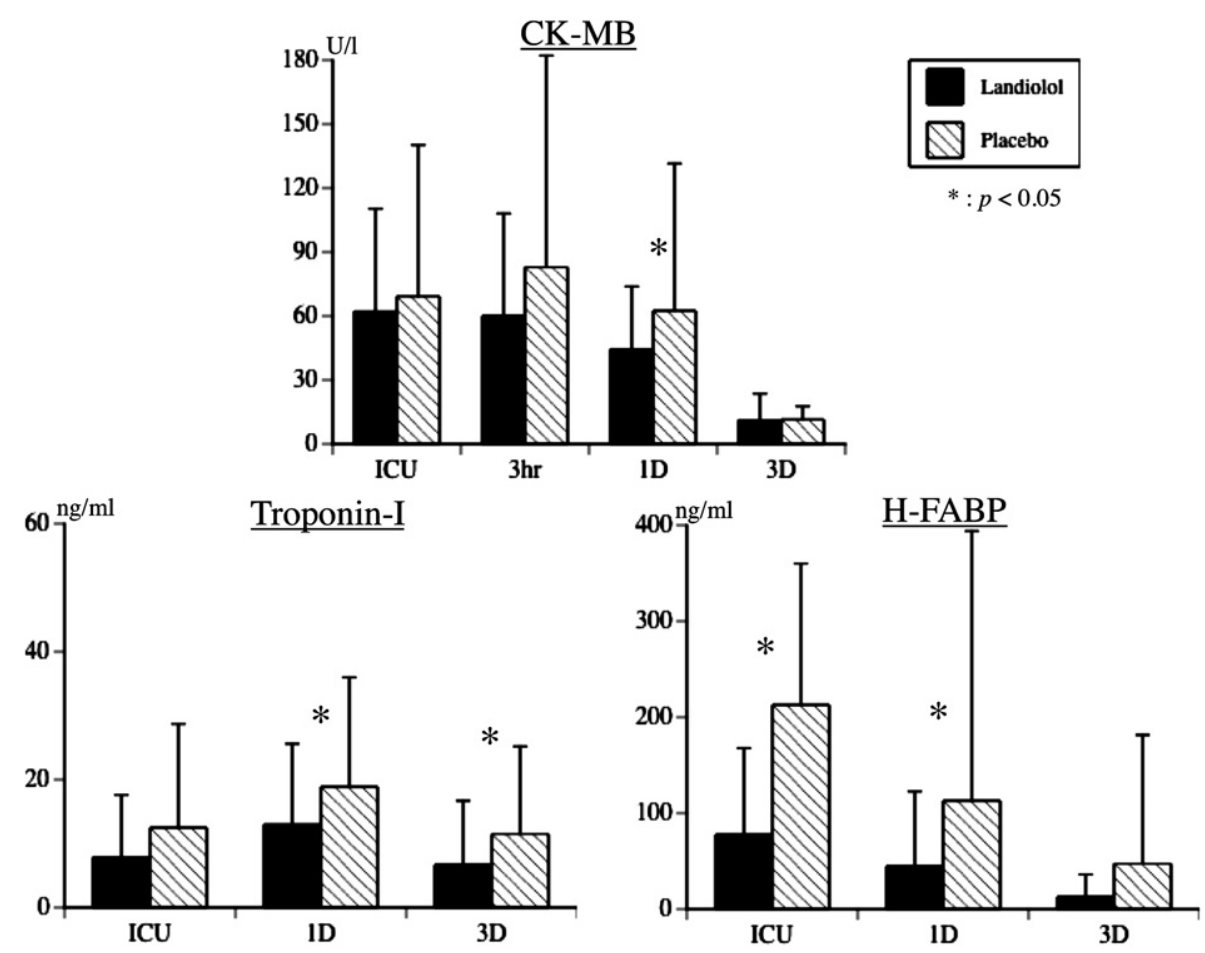

FIGURE 5. Ischemia-reperfusion injury parameters: CK-MB on postoperative day 1 , troponin-I on postoperative days 1 and 3 , and human heart fatty acidbinding protein on postoperative day 1 (at the time of returning to ICU) were significantly lower in the landiolol group compared with the placebo group. $C K$ $M B$, Creatine kinase isoenzyme $M B ; H-F A B P$, human heart fatty acid-binding protein.

between the 2 groups $(P=.6757)$. The incidence of Af $(\mathrm{n}=19,79.2 \%)$ was higher on postoperative days 2 to 4 , when patients are reported to be susceptible to postoperative Af, in the placebo group $(\mathrm{n}=19,79.2 \%)$ compared with the landiolol group $(\mathrm{n}=3,42.9 \%)(P=.1504)$ (Figure 2$)$.

In this study, $\beta$-blockers were administered orally in 34 patients after surgery. Fourteen of these patients were treated with landiolol and 20 patients were treated with placebo, and there was no statistically significant difference between the groups $(P=.3245)$.

\section{Secondary End Points}

Operative mortality and complications. There were no perioperative deaths in the landiolol group versus 2 such deaths in the placebo group (mediastinitis and cardiac failure) $(P=.1699)$ (Table 2). Perioperative complications occurred in 3 patients in the landiolol group versus 6 patients in the placebo group $(P=.4931)$. In the landiolol group, the complications were low output syndrome, acute renal failure, and cerebral infarction in 1 patient each. In the placebo group, 2 patients had heart failure, and 1 each had low output syndrome, refractory arrhythmia, mediastinitis, and cerebral infarction.

Hemodynamics. No significant differences were observed between the 2 groups with respect to the preoperative systolic blood pressure, diastolic blood pressure, and heart rate (Figure 3). No significant differences were seen with respect to postoperative blood pressure, but the heart rate was significantly lower in the landiolol group after discontinuation of administration.

Fluid balance. There were no intraoperative or postoperative differences of fluid balance between the 2 groups (Figure 4).

Parameters of ischemia-reperfusion injury. On postoperative day 1, the CK-MB level was $44.5 \pm 29.4 \mathrm{U} / \mathrm{L}$ in the landiolol group and $62.5 \pm 69.0 \mathrm{U} / \mathrm{L}$ in the placebo group, with the landiolol group having a significantly lower CK-MB level $(P=.0463)$ (Figure 5). Troponin-I was $13.0 \pm$ $12.6 \mathrm{ng} / \mathrm{mL}$ in the landiolol group and $18.9 \pm 17.1 \mathrm{ng} / \mathrm{mL}$ in the placebo group on postoperative day 1 , and $6.7 \pm$ $10.0 \mathrm{ng} / \mathrm{mL}$ and $11.5 \pm 13.7 \mathrm{ng} / \mathrm{mL}$, respectively, on postoperative day 3 . The landiolol group showed significantly lower values on both day $1(P=.0226)$, and day 3 $(P=.0365)$. Human heart fatty acid-binding protein was $77.8 \pm 90.0 \mathrm{ng} / \mathrm{mL}$ in the landiolol group and $212.9 \pm$ $547.7 \mathrm{ng} / \mathrm{mL}$ in the placebo group at the return to ICU, as well as $44.8 \pm 77.8 \mathrm{ng} / \mathrm{mL}$ in the landiolol group and $113.2 \pm 281.5 \mathrm{ng} / \mathrm{mL}$ in the placebo group on postoperative day 1 . The landiolol group showed lower values (return to ICU: $P=.0472$, postoperative day $3: P=.0425$ ).

Inflammatory parameters data. No statistically significant differences were observed between the 2 groups with respect to preoperative hs-CRP, IL-6, and IL-8 levels (Figures 6 and 7). hs-CRP was significantly lower in the 

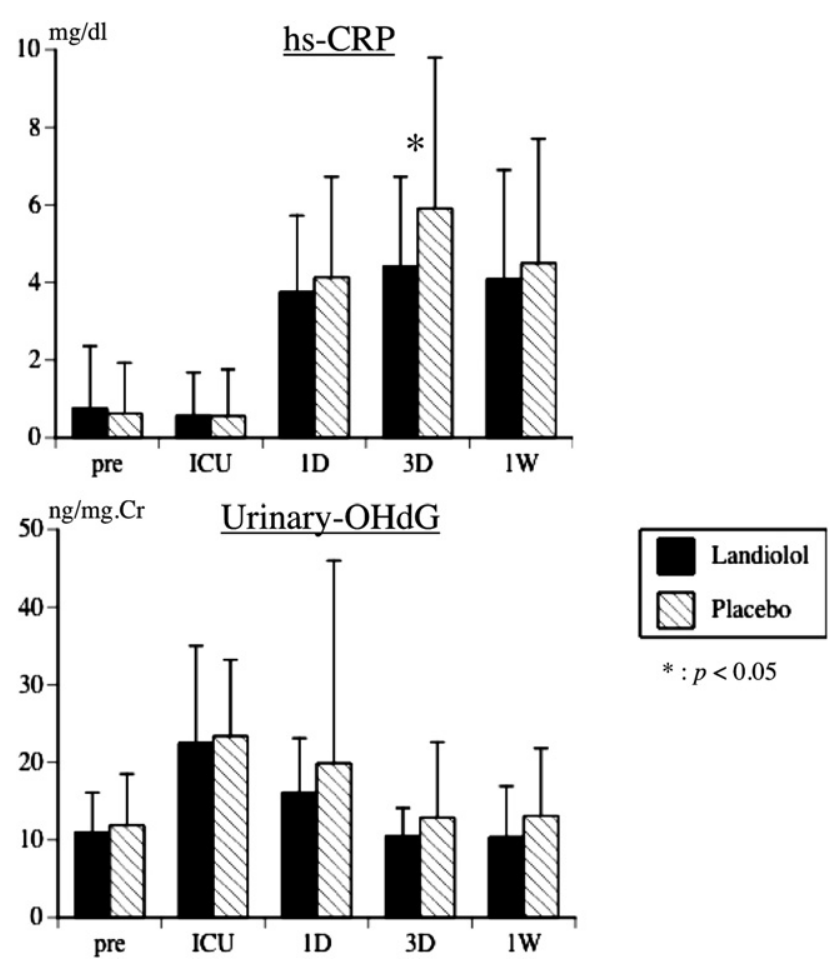

FIGURE 6. hs-CRP (upper) and urinary 8-hydroxydeoxyguanosine (lower). hs-CRP was significantly lower on postoperative day 3 in the landiolol group compared with the placebo group, but urinary 8-hydroxydeoxyguanosine showed no significant difference between the 2 groups.

landiolol group compared with the placebo group on postoperative day $3(P=.0070)$. IL-6 was $22.4 \pm 15.7 \mathrm{pg} / \mathrm{mL}$ in the landiolol group and $36.9 \pm 36.1 \mathrm{pg} / \mathrm{mL}$ in the placebo group on postoperative day 1 , whereas it was $13.7 \pm 12.2$ $\mathrm{pg} / \mathrm{mL}$ and $27.3 \pm 25.9 \mathrm{pg} / \mathrm{mL}$, respectively, on day 3 . The landiolol group showed significantly lower values compared with the placebo group (postoperative day 1: $P=.0481$; postoperative day $3: P=.0172$ ). IL-8 was $16.9 \pm 11.9 \mathrm{pg} / \mathrm{mL}$ in the landiolol group and $28.8 \pm$ $26.6 \mathrm{pg} / \mathrm{mL}$ in the placebo group on returning to the ICU, being significantly lower in the landiolol group $(P=.0302)$.

Medical costs. The cost of landiolol treatment was $\$ 413.76$. The average cost of hospital treatment was $\$ 35,679.48 \pm \$ 6273.40$ in the landiolol group versus $\$ 39,981.43 \pm \$ 13,417.62$ in the placebo group, with the cost being significantly lower in the landiolol group $(P=.0202)$.

\section{Factors Related to Occurrence of Atrial Fibrillation}

In regard to preoperative factors, there were significant differences in age, euroSCORE, preoperative KL-6, landiolol use, hospital stay, and medical costs between patients with and without Af (Table 3).

When risk factors for Af were investigated by univariate analysis, significant factors were age 70 years or more,
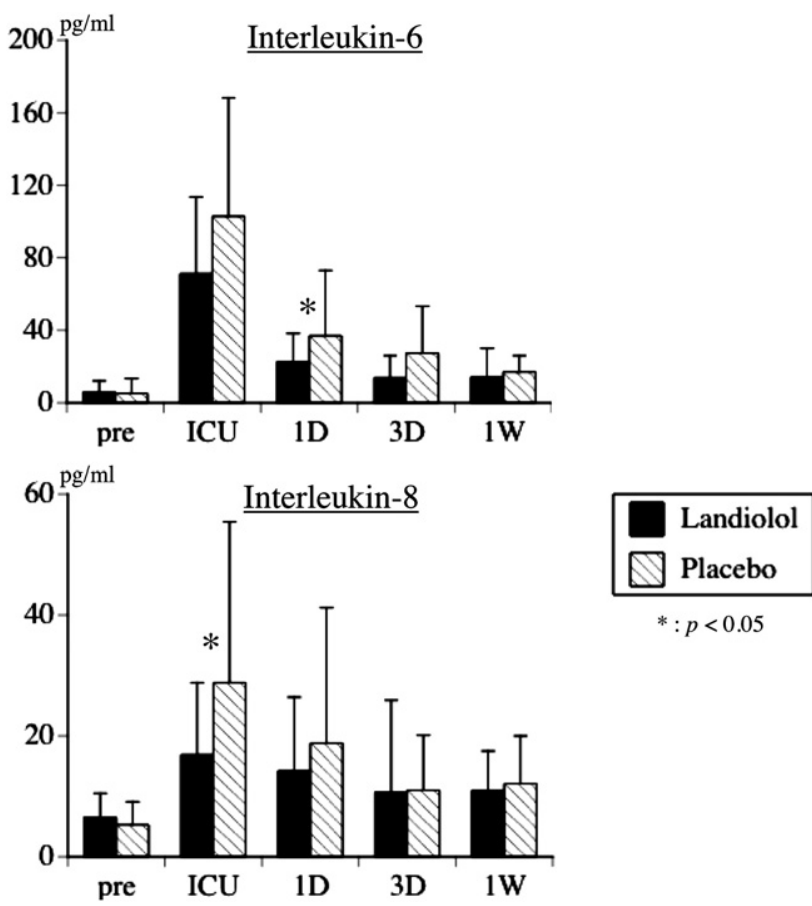

FIGURE 7. IL-6 (upper) and IL-8 (lower). IL-6 (on postoperative days 1 and 3 ) and IL-8 (on returning to ICU) were significantly lower in the landiolol group than in the placebo group.

euroSCORE of 10 or more, preoperative serum KL-6 300 $\mathrm{U} / \mathrm{mL}$ or more, preoperative serum I-CTP $10 \mathrm{ng} / \mathrm{mL}$ or more, preoperative non-use of angiotensin receptor blockers (ARB), and non-use of landiolol. According to multivariate analysis, significant factors were a euroSCORE of 10 or more, preoperative non-use of ARB, and non-use of landiolol (Table 4).

\section{DISCUSSION}

In this study, we could reduce the incidence of postoperative Af to $10 \%$ with the use of landiolol hydrochloride. Previous studies using $\beta$-blockers or amiodarone have reported significant reductions in postoperative Af compared with placebo; however, the incidence varied widely from $3 \%$ to $34 \%{ }^{4,10,11}$ In the present study, the incidence of postoperative Af was $10 \%$, which was similar to the values in previous reports. This $\beta$-blocker has strong antiischemic and anti-inflammatory effects, as well as strong sympathoinhibitory and cardiodepressant effects. However, because our study did not make comparisons with other drugs, this should be examined in future studies. In addition, to reduce postoperative Af, studies using increased doses of landiolol hydrochloride, longer treatment periods, or shifting to oral $\beta$-blockers or antiarrhythmic drugs are needed. Heart rates were significantly lower even after discontinuing landiolol regardless of its 4-minute half-life. This may be because myocardial protection through the 
TABLE 3. Relation of various factors to postoperative atrial fibrillation

\begin{tabular}{|c|c|c|c|}
\hline & $\mathbf{A f}+$ & Af - & $P$ value \\
\hline No. & 31 & 109 & \\
\hline Age (y) & $70.5 \pm 7.6$ & $66.7 \pm 9.4$ & .0461 \\
\hline Gender & $29: 2$ & $99: 10$ & 1.00 \\
\hline Body surface area $\left(\mathrm{m}^{2}\right)$ & $1.76 \pm 0.15$ & $1.69 \pm 0.18$ & .0636 \\
\hline euroSCORE & $7.2 \pm 3.7$ & $5.4 \pm 3.3$ & .0068 \\
\hline Emergency surgery & 11 & 25 & .1584 \\
\hline Ejection fraction $(\%)$ & $55.6 \pm 12.1$ & $54.9 \pm 14.4$ & .8192 \\
\hline \multicolumn{4}{|l|}{ Risk factors } \\
\hline Diabetes mellitus & 16 & 56 & 1.00 \\
\hline Hypertension & 26 & 82 & .4671 \\
\hline Hyperlipidemia & 21 & 57 & .1535 \\
\hline Obesity & 8 & 19 & .3091 \\
\hline Smoking & 13 & 45 & 1.00 \\
\hline $\begin{array}{l}\text { Cerebrovascular } \\
\text { disease }\end{array}$ & 1 & 5 & 5 \\
\hline Chronic renal failure & 5 & 19 & 1.00 \\
\hline \multicolumn{4}{|l|}{ Oral medications } \\
\hline ARB & 11 & 65 & .0240 \\
\hline ACE-I & 2 & 8 & 1.0 \\
\hline $\mathrm{Ca}$ antagonist & 15 & 37 & .1480 \\
\hline Beta-blocker & 11 & 31 & .5072 \\
\hline Aldosterone blocker & 3 & 6 & .4147 \\
\hline Statin & 12 & 33 & .3901 \\
\hline hs-CRP (mg/dL) & $0.74 \pm 1.1$ & $0.68 \pm 1.5$ & .8534 \\
\hline IL-6 (pg/mL) & $5.1 \pm 3.1$ & $5.6 \pm 7.7$ & .8284 \\
\hline IL-8 (pg/mL) & $6.4 \pm 4.1$ & $6.0 \pm 3.9$ & .7307 \\
\hline $\begin{array}{l}\text { Urinary OHdG } \\
\text { (ng/mg Cr) }\end{array}$ & $11.2 \pm 5.2$ & $11.4 \pm 5.8$ & .9350 \\
\hline KL-6 (U/mL) & $299.1 \pm 108.0$ & $207.5 \pm 99.0$ & $<.0001$ \\
\hline I-CTP (ng/mL) & $12.1 \pm 10.4$ & $8.9 \pm 10.8$ & .1791 \\
\hline Hyaluronic acid (ng/mL) & $58.0 \pm 53.0$ & $45.0 \pm 41.8$ & .1427 \\
\hline Landiolol use & 7 & 63 & .0009 \\
\hline \multicolumn{4}{|l|}{ Oral medications } \\
\hline $\mathrm{ARB}$ & 16 & 52 & .8389 \\
\hline ACE-I & 1 & 4 & 1.00 \\
\hline $\mathrm{Ca}$ antagonist & 15 & 59 & .6841 \\
\hline Beta-blocker & 9 & 25 & .4845 \\
\hline Aldosterone blocker & 24 & 78 & 6489 \\
\hline Statin & 21 & 63 & .4070 \\
\hline ACCT (min) & $22.5 \pm 9.3$ & $22.8 \pm 9.1$ & .1923 \\
\hline ECCT (min) & $113.1 \pm 37.8$ & $101.6 \pm 25.6$ & .1514 \\
\hline Hospital stay (d) & $14.6 \pm 8.6$ & $12.0 \pm 5.7$ & .0498 \\
\hline Hospital cost & $\begin{array}{r}\$ 35,679.48 \pm \\
\$ 6273.40\end{array}$ & $\begin{array}{r}\$ 39.981 .43 \pm \\
\$ 13,417.62\end{array}$ & .0109 \\
\hline
\end{tabular}

$A f$. Atrial fibrillation; $A R B$, angiotensin II receptor blocker; $A C E-I$, angiotensinconverting enzyme inhibitor; $h s-C R P$, highly sensitive C-reactive protein; $O H d G$, 8-hydroxydeoxyguanosine; $K L-6$, sialylated carbohydrate antigen KL-6; I-CTP, pyridinoline cross-linked telopeptide of type I collagen.

anti-ischemic, anti-inflammatory, and sympathoinhibitory effects of landiolol during the postoperative acute phase also stabilized the heart rate after discontinuation.

Prophylactic administration of oral $\beta$-blockers has already been recommended for this purpose. ${ }^{12}$ Crystal and colleagues ${ }^{19}$ performed a meta-analysis of 27 trials and found that postoperative Af occurred in 33\% of the control group versus $19 \%$ of the $\beta$-blocker group. They also performed a meta-analysis of 8 trials of sotalol therapy and found significantly less postoperative Af in the sotalol group (17\%) compared with the control group (37\%).

There have already been some reports about the efficacy of intravenous $\beta$-blockers, but few RCTs have been performed. The chief reason is probably that traditional intravenous $\beta$-blockers can cause hypotension because of their cardiodepressant effect. ${ }^{20,21}$

This study investigated landiolol hydrochloride, which has a half-life of approximately 4 minutes (shorter than that of conventional intravenous $\beta$-blockers ${ }^{16}$ ) and is unlikely to cause hypotension because its $\beta_{1} / \beta_{2}$ selectivity ratio is approximately $250: 1$ and it has little negative inotropic effect. ${ }^{17,18}$ Sasao and colleagues ${ }^{18}$ reported that landiolol caused a dose-dependent decrease of the heart rate in animals, but no change of mean blood pressure, whereas esmolol decreased both the heart rate and the blood pressure. In the present study, landiolol did not decrease the blood pressure or cause cardiac failure, while having a marked preventive effect on postoperative Af.

Various factors have been reported to show an association with Af after cardiac surgery, including advanced age, cardiac dysfunction, inflammation, ischemia-reperfusion injury, oxidative stress, fibrosis, and sympathetic hypertonia. ${ }^{1-9}$ This research indicated that landiolol has anti-ischemic action, anti-inflammatory action, and sympatholytic effects. In the present study, CPK-MB, troponin-I, and heart fatty acid-binding protein were significantly lower in the landiolol group, suggesting that prevention of ischemia might have reduced the occurrence of Af. Postoperative tachycardia increases myocardial oxygen consumption and causes myocardial ischemia by decreasing coronary artery blood flow. Beta-blockers are said to decrease myocardial oxygen consumption and prevent myocardial ischemia. ${ }^{22}$ Landiolol has not been adequately studied, but its antiischemic effects were evident in animal experiments, ${ }^{23}$ and they were also clear from the results of this study.

It has been reported that production of IL-6 is inhibited by $\beta$-blockers in patients with unstable angina. ${ }^{24}$ Invasion due to cardiac surgery induces an increase in cytokines and causes an intensive inflammatory response. This is considered to be strongly related to occurrence of Af. The present study suggests that landiolol hydrochloride may be an anti-inflammatory drug. Because postoperative increases in IL-6 and IL-8 were limited in the study, it is highly likely that the anti-inflammatory effect of landiolol hydrochloride reduced the occurrence of Af. Lo and colleagues ${ }^{8}$ reported that inflammation is related to postoperative Af and the incidence of Af is higher in patients with a preoperative CRP $3.0 \mathrm{mg} / \mathrm{dL}$ or more. In the present study, only 6 patients had a preoperative hs-CRP of $3.0 \mathrm{mg} / \mathrm{dL}$ or more, and preoperative inflammation was unrelated to the occurrence of Af. 
TABLE 4. Risk factors for postoperative atrial fibrillation

\begin{tabular}{|c|c|c|c|c|}
\hline & \multicolumn{2}{|c|}{ Univariate } & \multicolumn{2}{|c|}{ Multivariate } \\
\hline & Odds ratio $(95 \% \mathrm{CI})$ & $P$ value & Odds ratio $(95 \% \mathrm{CI})$ & $P$ value \\
\hline \multicolumn{5}{|l|}{ Preoperative factors } \\
\hline Age $>70 y$ & $2.53(1.11-5.73)$ & .0266 & $2.44(0.85-7.00)$ & .0962 \\
\hline euroSCORE $>10$ points & $8.153(3.12-21.3)$ & $<.0001$ & $7.10(2.01-25.1)$ & .0023 \\
\hline Ejection fraction $>40 \%$ & $0.70(0.22-2.24)$ & .5498 & & \\
\hline $\mathrm{hs}-\mathrm{CRP}>3.0 \mathrm{mg} / \mathrm{dL}$ & $0.57(0.07-4.94)$ & 6118 & & \\
\hline $\mathrm{KL}-6>300 \mathrm{U} / \mathrm{mL}$ & $7.43(1.43-38.8)$ & .0174 & $1.45(0.20-10.7)$ & .7177 \\
\hline $\mathrm{I}-\mathrm{CTP}>10 \mathrm{ng} / \mathrm{mL}$ & $4.33(1.16-16.3)$ & .0298 & $1.79(0.33-9.77)$ & .5011 \\
\hline Hyaluronic acid $>80 \mathrm{ng} / \mathrm{mL}$ & $2.93(0.80-10.7)$ & .1034 & & \\
\hline ARB & $0.37(0.16-0.85)$ & .0195 & $0.25(0.08-0.76)$ & .0142 \\
\hline ACE-I & $0.87 \mathrm{n}(0.18-4.33)$ & .8656 & & \\
\hline Calcium antagonist & $1.82(0.81-4.09)$ & .1149 & & \\
\hline Beta-blocker & $1.38(0.59-3.22)$ & .4512 & & \\
\hline Aldosterone blocker & $1.84(0.43-7.82)$ & .4093 & & \\
\hline Statin & $1.46(0.63-3.34)$ & .3764 & & \\
\hline \multicolumn{5}{|c|}{ Intraoperative/postoperative factors } \\
\hline ACCT $>40 \mathrm{~min}$ & $2.81(0.60-13.3)$ & .1921 & & \\
\hline $\mathrm{ECCT}>120 \mathrm{~min}$ & $2.12(0.87-5.19)$ & .1003 & & \\
\hline Landiolol & $0.21(0.09-0.54)$ & .0010 & $0.22(0.07-0.67)$ & .0079 \\
\hline ARB & $1.17(0.53-2.60)$ & .7011 & & \\
\hline ACE-I & $0.88(0.09-8.12)$ & .9065 & & \\
\hline Calcium antagonist & $0.79(0.36-1.77)$ & .5725 & & \\
\hline Beta-blocker & $1.38(0.56-3.36)$ & .4860 & & \\
\hline Aldosterone blocker & $0.78(0.34-1.78)$ & .5570 & & \\
\hline Statin & $1.53(0.66-3.57)$ & .3206 & & \\
\hline
\end{tabular}

$C R P$, C-reactive protein; $K L-6$, sialylated carbohydrate antigen KL-6; I-CTP, pyridinoline cross-linked telopeptide of type I collagen; $A R B$, angiotensin II receptor blocker; $A C E-I$, angiotensin-converting enzyme inhibitor; $A C C T$, aortic crossclamping time; $E C C T$, extracorporeal circulation time.

Postoperative levels of IL-6, IL-8, and hs-CRP were significantly lower in the landiolol group, suggesting that the anti-inflammatory effect of this drug might have reduced the occurrence of Af.

This study investigated the risk factors for postoperative Af by univariate and multivariate analyses. We found that advanced age and high levels of fibrosis marker were risk factors for Af, as previously reported, and determined that preoperative ARB therapy was associated with a lower incidence of postoperative Af. Preoperative oral treatment with $\beta$-blockers, angiotensin-converting enzyme inhibitors (ACE-I), and statins has been reported to decrease postoperative $\mathrm{Af},{ }^{5}$ but there has been little information about ARB. Ozaydin and colleagues ${ }^{25}$ reported that preoperative ACE-I therapy was associated with less frequent Af after CABG. Guler and colleagues ${ }^{26}$ reported a significantly higher angiotensin-II level on postoperative day 2 in patients with Af. Because angiotensin-II promotes electrophysiologic and structural remodeling, ${ }^{26,27}$ postoperative Af may be prevented by inhibiting angiotensin-II with ACE-I or ARB therapy. We previously reported that lowdose infusion of human atrial natriuretic peptide from the start of cardiopulmonary bypass during cardiac surgery improved the outcome $\mathrm{e}^{28}$ and reduced the occurrence of postoperative Af. $^{29}$ Atrial natriuretic peptide inhibits the renin-angiotensin-aldosterone system ${ }^{28,30}$ and reduces postoperative angiotensin-II levels, which might prevent Af. Because ARB therapy also inhibits angiotensin-II, postoperative Af could be decreased by preoperative ARB administration in this manner, but further investigation is needed.

This study also investigated the influence of Af on medical costs. It has been reported that postoperative Af prolongs the hospital stay and increases costs. Mahoney and colleagues ${ }^{31}$ reported that amiodarone was effective for preventing postoperative Af, particularly in elderly patients and patients with complications. Gillespie and colleagues ${ }^{32}$ found that $\beta$-blocker prophylaxis shortened the hospital stay by 2.2 days and decreased total hospital costs by $25.7 \%$. In this study, medical costs were significantly lower in the landiolol group than in the placebo group. Although the cost of landiolol in the landiolol group is approximately $\$ 400$, the average cost for the landiolol group was still significantly lower than that for the placebo group. Because drugs and longer hospital stays are required for Af treatment, and the hospital stay of the placebo group was actually longer by approximately 3 days, these factors were considered to increase the average cost. Oral drugs are less expensive than injectable drugs; however, it has been reported that intravenous administration reduces Af more 
than oral administration, ${ }^{33}$ and intravenous administration is more effective in reducing postoperative Af during the acute postoperative phase of postoperative period.

This study was the first comparative study of the new ultra-short-acting $\beta$-blocker landiolol hydrochloride compound with placebo. In the future, the efficacy and problems related to landiolol hydrochloride should be clarified in comparative studies with amiodarone and other $\beta$-blockers recommended in the American College of Cardiology/ American Heart Association guideline. Further study is necessary.

\section{CONCLUSIONS}

Postoperative Af was significantly less common in the landiolol group compared with the placebo group $(10 \%$ vs $34.3 \%$ ), and Af was reduced by intravenous landiolol hydrochloride without causing hypotension or bradycardia. It is possible that landiolol hydrochloride will eventually become part of the regimen for perioperative management of patients undergoing cardiac surgery.

The authors thank Hiroyuki Udagawa, Medical Processing Section, Nihon University Itabashi Hospital, for extracting the health cost data for this study.

\section{References}

1. Zaman AG, Archbold RA, Helft G, Paul EA, Curzen NP, Mills PG. Atrial fibrillation after coronary artery bypass surgery: a model for preoperative risk stratification. Circulation. 2000;101:1403-8.

2. Amar D, Shi W, Hogue CW Jr, Zhang H, Passman RS, Thomas B, Bach PB, et al. Clinical prediction rule for atrial fibrillation after coronary artery bypass grafting. J Am Coll Cardiol. 2004;44:1248-53.

3. Villareal RP, Hariharan R, Liu BC, Kar B, Lee VV, Elayda M, et al. Postoperative atrial fibrillation and mortality after coronary atrial bypass surgery. J Am Coll Cardiol. 2004;43:742-8.

4. Budeus M, Hennersdorf M, Perings S, Röhlen S, Schnitzler S, Felix O, et al. Amiodarone prophylaxis for atrial fibrillation of high-risk patients after coronary bypass grafting: a prospective, double-blinded, placebo-controlled, randomized study. Eur Heart J. 2006;27:1584-91.

5. Mathew JP, Fontes ML, Tudor IC, Ramsay J, Duke P, Mazer CD, et al. Investigators of the Ischemia Research and Education Foundation; Multicenter Study of Perioperative Ischemia Research Group. A multicenter risk index for atrial fibrillation after cardiac surgery. JAMA. 2004;291:1720-9.

6. Mariscalco G, Klersy C, Zanobini M, Banach M, Ferrarese S, Borsani P, et al. Atrial fibrillation after isolated coronary surgery affects late survival. Circulation. 2008;118:1612-8.

7. Sezai A, Hata M, Niino T, Kasamaki Y, Nakai T, Hirayama A, et al. Study of the factors related to atrial fibrillation after coronary artery bypass grafting: a search for a marker to predict the occurrence of atrial fibrillation before surgical intervention. J Thorac Cardiovasc Surg. 2009;137:895-900.

8. Lo B, Fijnheer R, Nierich AP, Bruins P, Kalkman CJ. C-reactive protein is a risk indicator for atrial fibrillation after myocardial revascularization. Ann Thorac Surg. 2005;79:1530-5.

9. Nakai T, Chandy J, Nakai K, Bellows WH, Flachsbart K, Lee RJ, et al. Histologic assessment of right atrial appendage myocardium in patients with atrial fibrillation after coronary artery bypass graft surgery. Cardiology. 2007;108:90-6.

10. Giri S, White CM, Dunn AB, Felton K, Freeman-Bosco L, Reddy P, et al. Oral amiodarone for prevention of atrial fibrillation after open heart surgery, the Atrial Fibrillation Suppression Trial (AFIST): a randomized placebo-controlled trial. Lancet. 2001;357:830-6.

11. Gomes JA, Ip J, Santoni-Rugiu F, Mehta D, Ergin A, Lansman S, et al. Oral d, 1 sotalol reduces the incidence of postoperative atrial fibrillation in coronary ar- tery bypass surgery patients: a randomized, double-blind, placebo-controlled study. J Am Coll Cardiol. 1999;34:334-9.

12. Fuster V, Rydén LE, Cannom DS, Crijns HJ, Curtis AB, Ellenbogen KA, et al, American College of Cardiology/American Heart Association Task Force on Practice Guidelines; European Society of Cardiology Committee for Practice Guidelines, European Heart Rhythm Association, Heart Rhythm Society. ACC/AHA/ ESC 2006 guideline for management of patients with atrial fibrillation: a report of the American College of Cardiology/ American Heart Association task force on practice guidelines and the European Society of Cardiology committee for practice guidelines (writing committee to revise the 2001 guidelines for the management of patients with atrial fibrillation): developed in collaboration with the European Heart Rhythm Association and Heart Rhythm Society. Circulation. 2006;114:e257-e354.

13. Andrews TC, Reimold SC, Berlin JA, Antmaan EM. Prevention of supraventricular arrhythmias after coronary artery bypass surgery: a meta-analysis of randomized control trials. Circulation. 1991;84(suppl III):III-236-44.

14. Matangyi MF, Neutze JM, Graham KJ, Hill DG, Kerr AR, Barratt-Boyes BG. Arrhythmia prophylaxis after aorta-coronary bypass: the effect of minidose propranolol. J Thorac Cardiovasc Surg. 89;439-43.

15. Eagle KA, Guyton RA, Davidoff R, Edwards FH, Ewy GA, Gardner TJ, et al. ACC/AHA 2004 guideline update for coronary artery bypass graft surgery. a report of the American College of Cardiology/American Heart Association task force on practice guidelines (committee to update the 1999 guidelines for coronary artery bypass surgery. the American Association for Thoracic Surgery, and the Society of Thoracic Surgeons. J Am Coll Cardiol. 2004;44:e213-e310.

16. Iguchi S, Iwamura H, Nishizaki M, Hayashi A, Senokuchi K, Kobayashi K, et al. Development of a highly cardioselective ultra short-acting beta-blocker, ONO-1101. Chem Pharm Bull (Tokyo). 1992;40:1462-9.

17. Sugiyama A, Takahara A, Hashimoto K. Electrophysiologic cardiohemodynamic and beta-blocking actions of a new ultra-short-acting beta blocker, ONO-1101, assessed by the in vivo canine model in comparison with esmolol. J Cardiovasc Pharmacol. 1999;34:70-7.

18. Sasao J, Tarver SD, Kindscher JD, Taneyama C, Benson KT, Goto H. In rabbits, landiolol, a new ultra-short-acting $\beta$-blocker, exerts a more potent negative chronotropic effect and less effect on blood pressure than esmolol. Can J Anesth. 2001;48:485.

19. Crystal E, Connolly SJ, Sleik K, Ginger TJ, Yusuf S. Interventions on prevention of postoperative atrial fibrillation in patients undergoing heart surgery: a metaanalysis. Circulation. 2002;106:75-80.

20. Maniar PB, Balcetyye-Harris N, Tamis JE, Steinberg JS. Intravenous versus oral beta-blockers for prevention of post-CABG atrial fibrillation in high-risk patients identified by signal-averaged ECG: lessons of a pilot study. Card Electrophysiol Rev. 2003;7:158-61.

21. Mooss AN, Wurdeman RL, Mohiuddin SM, Reyes AP, Sugimoto JT, Scott W, et al. Esmolol versus diltiazem in the treatment of postoperative atrial fibrillation/atrial flutter after open heart surgery. Am Heart J. 2000;140:176-80.

22. Mangano DT, Layug EL, Wallace A, Tateo I. Effect of atenolol on mortality and cardiovascular morbidity after noncardiac surgery. Multicenter study of perioperative ischemia research group. $N$ Engl J Med. 1996;335:1713-20.

23. Kimura-Kurosawa S, Kanaya N, Kamada N, Hirata N, Nakayama M, Namiki A. Cardioprotective effect and mechanism of action of landiolol on the ischemic reperfused heart. J Anesth. 2007;21:480-9.

24. Doo YC, Kim DM, Oh DJ, Ryu KH, Rhim CY, Lee Y. Effect of beta blockers on expression of interleukin- 6 and C-reactive protein in patients with unstable angina pectoris. Am J Cardiol. 2001;88:422-4.

25. Ozaydin M, Dede O, Varol E, Kapan S, Turker Y, Peker O, et al. Effect of renin-angiotensin aldosterone system blockers on postoperative atrial fibrillation. Int J Cardiol. 2008;127:362-7.

26. Guler N, Ozkara C, Dulger H, Kutay V, Sahin M, Erbilen E, et al. Do cardiac neuropeptides play a role in the occurrence of atrial fibrillation after coronary bypass surgery? Ann Thorac Surg. 2007;83:532-7.

27. Ehrlich JR, Hohnloser SH, Nattel S. Role of angiotensin system and effects of its inhibition in atrial fibrillation: clinical and experimental evidence. Eur Heart J. 2006;27:512-8.

28. Sezai A, Shiono M, Orime Y, Hata H, Hata M, Negishi N, et al. Low-dose continuous infusion of human atrial natriuretic peptide during and after cardiac surgery. Ann Thorac Surg. 2000;69:732-8.

29. Sezai A, Hata M, Wakui S, Niino T, Takayama T, Hirayama A, et al. Efficacy of continuous low-dose hANP administration in patients undergoing emergent coronary artery bypass grafting for acute coronary syndrome. Circ J. 2007;71: 1401-7. 
30. Sezai A, Hata M, Niino T, Yoshitake I, Unosawa S, Wakui S, et al. Influence of continuous infusion of low-dose human atrial natriuretic peptide on renal function during cardiac surgery. J Am Coll Cardiol. 2009;54:1058-64.

31. Mahoney EM, Thompson TD, Veleder E, Williams J, Weintraub WS. Costeffectiveness of targeting patients undergoing cardiac surgery for therapy with intravenous amiodarone to prevent atrial fibrillation. J Am Coll Cardiol. 2002; 40:737-45.
32. Gillespie EL, White CM, Kluger J, Sahni J, Gallagher R, Coleman CI. A hospita perspective on the cost-effectiveness of beta-blockade for prophylaxis of atrial fibrillation after cardiothoracic surgery. Clin Ther. 2005;27:1963-9.

33. Halonen J, Hakala T, Auvinen T, Karjalainen J, Turpeinen A, Uusaro A, et al. Intravenous administration of metoprolol is more effective than oral administration in the prevention of atrial fibrillation after cardiac surgery. Circulation. 2006;114 I-1-4. 